\title{
IMPLEMENTASI MODEL PEMBELAJARAN KOOPERATIF TIPE SNOWBALL THROWING UNTUK MENINGKATKAN HASIL BELAJAR IPA
}

\section{IMPLEMENTATION OF COOPERATIVE LEARNING MODEL TYPE SNOWBALL THROWING TO IMPROVE OF SAINS LEARNING OUTCOME}

\author{
Ira Mardiana ${ }^{1}$, Muhammad Syazali ${ }^{* *}$ \\ ${ }^{1}$ Sekolah Menengah Pertama Negeri 21 Mataram \\ ${ }^{2}$ Program Studi PGSD FKIP Universitas Mataram \\ *Email: m.syazali@unram.ac.id
}

Diterima: 16 Desember 2019. Disetujui: 18 Desember 2020. Dipublikasikan: 9 Januari2020

\begin{abstract}
Abstrak: Aktivitas dan hasil belajar ilmu pengetahuan alam (IPA) peserta didik SMPN 21 Mataram tergolong masih rendah. Proporsi peserta didik yang mendapat nilai diatas kriteria ketuntasan minimal (KKM) adalah $42,86 \%$, dan sebanyak $57.14 \%$ peserta didik lainnya mendapatkan nilai di bawah KKM, dengan rata-rata nilai 69. Salah satu penyebabnya adalah pembelajaran konvensional yang selama ini diimplementasikan kurang mengeksplorasi wawasan, sikap, tidak menarik, membuat peserta didik sering mengalami kesulitan dalam memahami konsep karena kurangnya keterlibatan peserta didik secara aktif mencobakan atau meneliti suatu rancangan percobaan dan menarik kesimpulan dan apa yang telah dicobakan tersebut. Tujuan penelitian ini adalah meningkatkan hasil belajar IPA peserta didik di SMPN 21 Mataram melalui implementasi model pembelajaran kooperatif tipe snowball throwing. Jenis penelitian ini adalah penelitian tindakan kelas (PTK) melalui 2 siklus. Peningkatan hasil belajar ditentukan berdasarkan adanya kenaikan pada rata-rata hasil belajar, pencapaian daya serap dan ketuntasan belajar. Kenaikan mengacu pada perbandingan antara nilai pada kondisi awal, siklus I dan siklus II. Hasil penelitian menunjukkan bahwa implementasi model pembelajaran kooperatif tipe snowball throwing dapat meingkatkan hasil belajar IPA peserta didik di SMPN 21 Mataram. Rata-rata hasil belajar meningkat dari 69 (kondisi awal), menjadi 73 (siklus I) dan 78 (siklus II). Peningkatan juga terjadi pada pencapaian daya serap dan ketuntasan belajar. Pencapaian daya serap meningkat dari $69.43 \%$ menjadi $73.33 \%$ dan $78.33 \%$. Adapaun ketuntasan belajar mengalami peningkatan dari $42.86 \%$ menjadi $57.14 \%$ dan $85.71 \%$.
\end{abstract}

Kata Kunci: Snowball Throwing, Hasil Belajar, Daya Serap, Ketuntasan Belajar

Abstract: Activities and learning outcomes of natural science students of SMP 21 Mataram are still relatively low. The proportion of students who scored above the minimum completeness criteria (KKM) was $42.86 \%$, and as many as $57.14 \%$ of other students scored below the KKM, with an average value of 69 . One reason is conventional learning that has been implemented less explore insights, attitudes, not interesting, making students often have difficulty in understanding the concept because of the lack of involvement of students actively trying or researching an experimental design and drawing conclusions and what has been tried. The purpose of this study is to improve the learning outcomes of science students at SMPN 21 Mataram through the implementation of a snowball throwing cooperative learning model. This type of research is classroom action research (CAR) through 2 cycles. Improved learning outcomes are determined based on an increase in average learning outcomes, achievement of absorption and mastery learning. Increase refers to the ratio between the initial conditions, cycle I and cycle II. The results showed that the implementation of the snowball throwing cooperative learning model could improve the learning outcomes of science students at SMPN 21 Mataram. Average learning outcomes increased from 69 (initial conditions), to 73 (cycle I) and 78 (cycle II). Improvements also occurred in achieving absorption and mastery learning. Achievement of absorption increased from $69.43 \%$ to $73.33 \%$ and $78.33 \%$. As for mastery learning has increased from $42.86 \%$ to $57.14 \%$ and $85.71 \%$.

Keywords: Snowball Throwing, learning outcomes, Achievement of Absorption and Mastery Learning

\section{PENDAHULUAN}

Ilmu Pengetahuan Alam (IPA) berkaitan dengan cara mencari tahu tentang alam secara sistematis, sehingga IPA bukan hanya kumpulan pengetahuan yang berupa fakta-fakta, konsepkonsep, atau prinsip-prinsip saja tetapi juga merupakan suatu proses penemuan [1]. IPA adalah suatu kumpulan teori yang sistematis, penerapannya secara umum terbatas pada gejala- gejala alam, lahir dan berkembang melalui metode ilmiah seperti observasi, eksperimen serta sikap ilmiah seperti rasa ingin tahu, jujur, dan terbuka.

Pada tingkat SMP/MTs proses pembelajaran Ilmu Pengetahuan Alam dan teknologi dimaksudkan untuk memperoleh kompetensi dasar ilmu pengetahuan dan teknologi serta membudayakan berpikir ilmiah secara kritis, kreatif, dan mandiri. Namun kenyataan di lapangan 
khususnya pada SMP Negeri 21 Mataram menunjukkan bahwa: (1) kualitas pengetahuan dan pemahaman terhadap materi pembelajaran Ilmu Pengetahuan Alam masih rendah, dan (2) kurang aktifnya peserta didik mengikuti pelajaran karena interaksi antara guru dengan peserta didik, peserta didik dengan peserta didik, dalam pembelajaran peserta didik lebih banyak pasif didalam menerima materi pembelajaran.

Hal ini terlihat dari hasil ulangan semester ganjil pada pelajaran IPA di kelas VIIIA SMP Negeri 21 Mataram Tahun Pelajaran 2016/2017 yang berjumlah 21 peserta didik hanya 9 peserta didik yang mendapatkan nilai lebih dari KKM. KKM di Sekolah SMP Negeri 21 Mataram adalah 75. Jika di persentasekan peserta didik yang mendapat nilai diatas KKM ada 42,86 \%, sedangkan $57,14 \%$ peserta didik lainnya mendapatkan nilai dibawah KKM, dengan ratarata nilai 69.

Rendahnya hasil belajar ini disebabkan oleh antara lain bahwa pembelajaran IPA seperti ini dianggap kurang mengeksplorasi wawasan, sikap, tidak menarik, membuat peserta didik sering mengalami kesulitan dalam memahami konsep karena kurangnya keterlibatan peserta didik secara aktif mencobakan atau meneliti suatu rancangan percobaan dan menarik kesimpulan dan apa yang telah dicobakan tersebut. Untuk mengatasi permasalahan tersebut maka perlu adanya upaya untuk meningkatkan hasil belajar peserta didik pada mata pelajaran IPA.

Untuk memecahkan masalah ini maka dipilih Model Pembelajaran Kooperatif Tipe Snowball Throwing dalam pembelajaran IPA peserta didik tidak hanya sekedar menerima informasi dari guru saja, karena dalam proses pembelajaran Cooperative Learning tipe Snowball Throwing mengarahkan peserta didik belajar dengan mengembangkan mindson activities dan hands-on activities. Beberapa penelitian sebelumnya juga menunjukkan bahwa penerapan model tersebut mampu meningkatkan hasil belajar IPA [2], [3], [4], [5], [6], [7], [8]. Model pembelajaran tersebut bahkan mampu meningkatkan keterampilan berpikir kritis [9].

\section{METODE PENELITIAN}

Penelitian tindakan ini dilaksnakan di kelas VIIIA SMP Negeri 21 Mataram yang berlamat di Jl. TGM. M. Rafi'i Hamdani Karang Pule Sekarbela Kota Mataram Nusa Tenggara Barat. Penelitian ini dilaksanakan pada semester genap tahun pelajaran 2016/2017, pelaksanaan tindakan selama 3 bulan kegiatan dimulai pada awal bulan Januari 2017 sampai dengan Maret 2017.

Subjek penelitian ini adalah peserta didik kelas VIIIA SMP Negeri 21 Mataram tahun pelajaran 2016/2017 yang terdiri atas 21 orang peserta didik, dengan jumlah peserta didik laki-laki 11 orang dan peserta didik perempuan 10 orang. Tahapan penelitian ini terdiri dari (1) perencanaan tindakan, (2) pelaksanaan tindakan, (3) observasi dan evaluasi, (4) refleksi di akhir tindakan Data hasil belajar peserta didik dianalisis secara deskriptif yaitu dengan menentukan skor rata-rata kelas. Skor rata-rata pada siklus I dibandingkan dengan skor rata-rata kelas pada siklus selanjutnya. Berhasil tidaknya peserta didik menguasai materi pembelajaran secara klasikal dapat diketahui melalui pencapaian daya serap (DS) dan ketuntasan belajar (KB). Kriteria keberhasilan untuk masingmasing siklus rata-rata kelas, daya serap (DS) dan ketuntasan belajar (KB) berturut-turut $75 \%$ dan $85 \%$.

\section{HASIL DAN PEMBAHASAN}

Dari analisis data hasil belajar peserta didik pada siklus I diketahui bahwa skor rata-rata hasil belajar $=73: \mathrm{DS}=73.33 \%, \mathrm{~KB}=57.14 \%$ meningkat dari data awal yang mencapai rerata = $69, \mathrm{DS}=69.43 \%, \mathrm{~KB}=42.86 \%$ dengan peningkatan sebesar $4 \%$ untuk rerata dan DS serta $14,29 \%$ untuk DS tetapi menurut kriteria keberhasilan yang telah ditetapkan hasil belajar peserta didik dikatakan tercapai apabila skor ratarata, DS, KB peserta didik berturut-turut $75.75 \%$ dan $85 \%$. Berdasarkan hal tersebut, maka skor ratarata, DS, dan KB peserta didik pada siklus I belum memenuhi kriteria keberhasilan yang ditetapkan.

Berdasarkan hasil refleksi tindakan yang dilakukan pada siklus I diadakan perbaikanperbaikan dalam pelaksanaan siklus II. Dalam pembelajaran siklus II peserta didik sudah mulai terbiasa dengan model pembelajaran yang diterapkan. Hal ini terlihat dari antausiasme peserta didik dalam mengerjakan tugas-tugas yang ada pada LKS sesuai petunjuk tanpa menunggu perintah. Interaksi peserta didik dalam satu kelompok sudah mulai berjalan terutama dalam hal saling berinteraksi.

Analisis data secara deskriptif menunjukkan bahwa hasil belajar peserta didik pada siklus I ke siklus II menunjukkan peningkatan, yakni skor rata-rata hasil belajar $(\mathrm{R})=78: \mathrm{DS}=78.33 \%, \mathrm{~KB}=$ $85.71 \%$. Dari kondisi ini diperoleh bahwa, skor rata-rata kelas, $\mathrm{DS}$, dan $\mathrm{KB}$ peserta didik pada siklus II masing-masing meningkat sebesar $5 \%, 5$ $\%$, dan $28.57 \%$ (Gambar 2). Hal tersebut sudah memenuhi kriteria keberhasilan penelitian.

Gambar 2 menunjukkan kecenderungan bahwa prestasi belajar peserta didik mengalami peningkatan. Demikian pula dengan perkembangan persentase ketuntasan belajar peserta didik. Artinya bahwa penerapan model pembelajaran kooperatif tipe Snowball Throwing memberikan dampak yang cukup signifikan dalam meningkatkan prestasi belajar IPA peserta didik kelas VIIIA SMP Negeri 
21 Mataram pada semester genap tahun pelajaran

$2016 / 2017$.

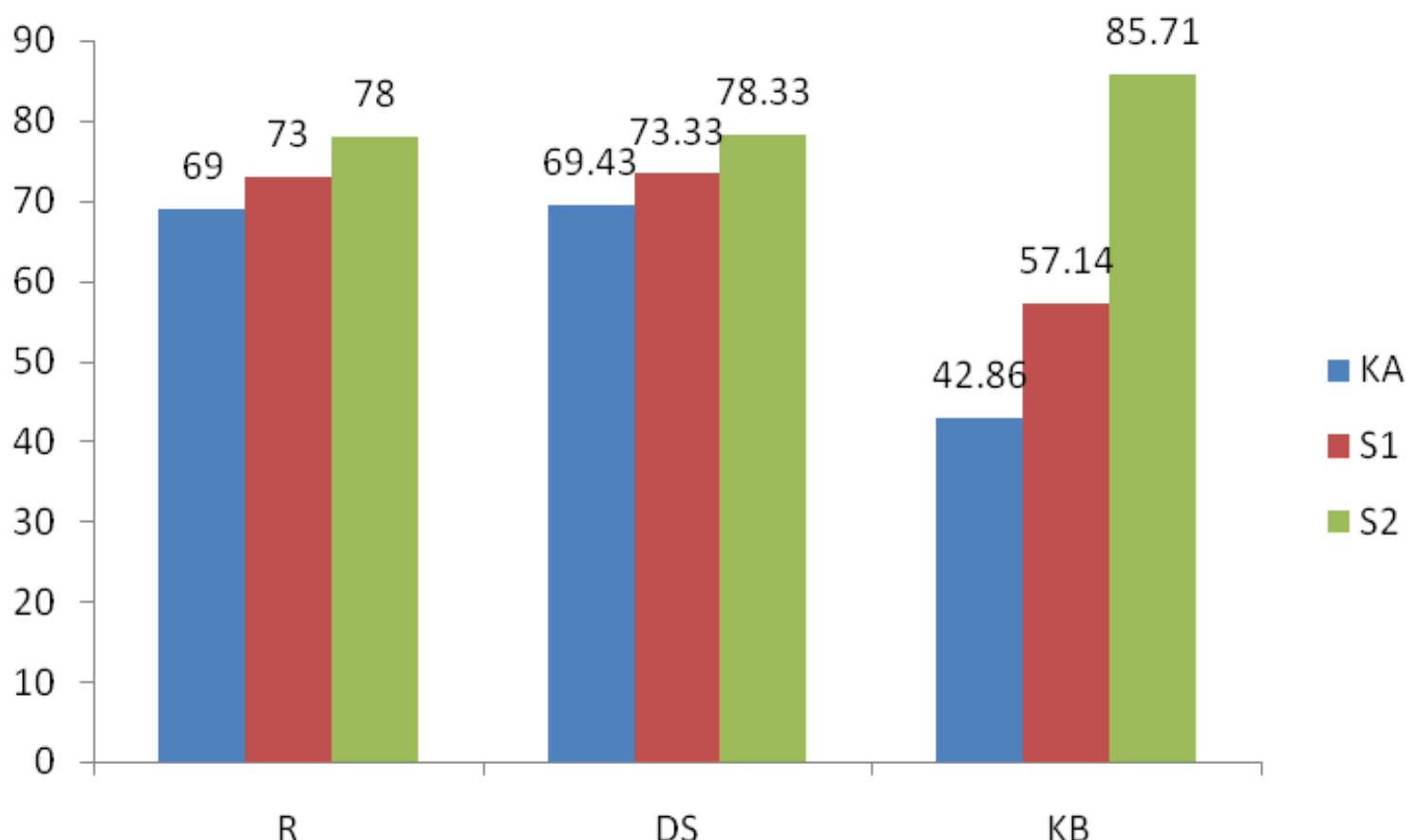

Gambar 2. Perbandingan antara rata hasil belajar (R), pencapaian daya serap (DS) dan ketuntasan belajar (KB) pada kondisi awal (KA), siklus I (S1) dan siklus II (S2).

Peningkatan dari R, DS dan KB peserta didik (Gambar 2) melalui implementasi model pembelajaran kooperatif tipe snowball throwing disebabkan oleh kelebihan-kelebihan dari model pembelajaran tersebut. Salah satunya adalah melatih keterampilan peserta didik dalam merumuskan pertanyaan berdasarkan topik yang diajarkan, dan saling memberikan pengetahuan antara sesama peserta didik [10].

Keterampilan bertanya merupakan salah satu keterampilan ranah abstrak yang dituntuk untuk dikuasai oleh peserta didik berdasarkan kurikulum 2013. Keterampilan ini juga merupakan salah satu tahapan dalam metode ilmiah. Metode ilmiah digunakan dalam melakukan penyelidikan ilmiah yang mengacu pada masalah hasil observasi. Melalui keterampilan tersebut, peserta didik dapat memulai untuk menjadi ilmuan.

Kelebihan kedua dari model pembelajaran kooperatif tipe snowball throwing adalah peserta didik memiliki pemahaman yang mendalam terkait topik yang dipelajari. Hal ini didorong oleh faktor tutor sebaya yang secara khusus disiapkan oleh guru. Proses ini melibatkan penglihatan, pendengaran, menulis dan berbicara mengenai topik yang didiskusikan kelompok. Pembelajaran tutor sebaya membuat peserta didik termotivasi dan

\section{KESIMPULAN}

Implementasi model pembelajaran kooperatif tipe snowball throwing dapat meningkatkan hasil belajar IPA peserta didik di SMPN 23 Mataram. Peningkatan hasil belajar tersebut dibuktikan aktif berpendapat. Pembelajaran tutor sebaya juga memberikan kesempatan sharing pikiran, dan saling bekerjasama, serta melatih keterampilan berkomunikasi [11].

Kelebihan ketiga adalah meningkatkan motivasi belajar peserta didik. Motivasi sendiri berpengaruh positif terhadap retensi, tanggung jawab dan hasil belajar IPA [12][13][14][15]. Dengan adanya motivasi, kegiatan belajar mengajar menjadi tidak sia-sia dan lebih bermakna. Peserta didik yang memiliki motivasi tinggi dalam belajar juga dapat lebih berkonsentrasi, fokus dan meluangkan waktu yang leibh banyak untuk memahami topik yang sedang dipelajari. Hal tersebut membuat siswa menguasai kompetensi dengan realtif lebih cepat.

Motivasi adalah faktor internal dari peserta didik yang berperan positif terhadap kepercayaan diri [16]. Kepercayaan diri merupakan keyakinan diri peserta didik dalam merespon sesuatu dengan baik sesuai kemampuan. Rasa percaya diri sangat mempengaruhi hasil belajar [17]. Kepercayaan diri siswa memiliki hubungan yang positif dan sifnifikan terhadap hasil belajar IPA [18]. Kepercayaan diri penting untuk menumbuhkan sikap belajar selama proses pembelajaran [19].

melalui adanya kenaikan rata-rata hasil belajar, pencapaian daya serap dan ketuntasan belajar.

\section{DAFTAR PUSTAKA}

[1]. Trianto. 2007. Model-Model Pembelajaran Inovatif Berorientasi Konstruktivis. Jakarta : Prestasi Pustaka. 
[2]. Dewi, N.L.P.K.T., Tegeh, I.M., dan Suartama, I.K. 2015. Pengaruh model snowball throwing berbantuan multimedia interaktif terhadap hasil belajar IPA. Journal Edutech 3(1): 1-11.

[3]. Wahyuningsih, S.W., Agung, A.A.G., dan Jampel, I.N. 2017. Pengaruh model pembelajaran snowball throwing bermediakan gambar terhadap hasil belajar ipa pada siswa kelas V SDN 1 Sangsit Buleleng. Mimbar PGSD 5(2): 1-10.

[4]. Arfini, N.K.B., Suarni, N.K., dan Arini, N.W. 2017. Pengaruh model pembelajaran snowball throwing bermuatan gerakan literasi sekolah terhadap hasil belajar IPA kelas IV SD. Mimbar SD 5(2): 1-10.

[5]. Hakiki, R.S., Arsyad, M., dan Khaeruddin. 2015. Upaya meningkatkan hasil belajar fisika siswa kelas VII SMP Negeri 30 Makassar melalui model pembelajaran kooperatif tipe snowball throwing. Jurnal Pendidikan Fisika 3(3): 284-294.

[6]. Latuperissa, F.B., dan Rumahlatu, D. 2018. penerapan model pembelajaran kooperatif tipe snowball throwing untuk meningkatkan hasil belajar siswa konsep sistem pernapasan manusia pada kelas XI SMA PGRI 1 Ambon. Biopendix 4(2): 102-108.

[7]. Wati, H., Rahardjanto, A., dan Huda, A.M. 2012. Penerapan kerangka rancangan tandur dalam model pembelajaran snowball throwing untuk meningkatkan hasil belajar IPA SMPN 03 Candipuro Lumajang. Jurnal Pendidikan Biologi Indonesia 1(1): 109-123.

[8]. Sutiani, K., Suarni, N.K., dan Dibia, I.K. 2018. Pengaruh model pembelajaran snowball throwing berbasis penilaian kinerja terhadap hasil belajar IPA. International Journal of Elementary School 2(3): 173-182.

[9]. Syahrina, I., Wahyuni, A., dan Susana. 2016. Kemampuan berpikir kritis melalui model snowball throwing terhadap hasil belajar materi fisika pada siswa kelas X1 SMAN 1 Montasik Aceh Besar tahun pelajaran 2015/2016. Jurnal Ilmiah Mahasiswa 1(4): 256-260.

[10]. Adhiatmika, MW., Agustina, K., dan Sindu, I.G.P. 2017. Pengaruh model pembelajaran kooperatif tipe snowball throwing terhadap hasil belajar siswa pada mata pelajaran TIK kelas VIII SMP Negeri 5 Tejakula. KARMAPATI 6(1): 214-223.

[11]. Sarini, N.K., Sudana, D.N., dan Riastini, P.N. 2018. Hasil Belajar Ipa Kelas IV SD di Gugus II Santalia Melalui Tutor Sebaya. Jurnal Ilmiah Sekolah Dasar 2(2): 94-102.

[12]. Daulay, U.A., Syarifudin, dan Manurung, B. 2016. Pengaruh Blended Learning Berbasis Edmodo dan Motivasi Belajar terhadap Hasil
Belajar IPA Biologi dan Retensi Siswa pada Sistem Peredaran Darah Manusia di Kelas VIII SMP Negeri 5 Medan. Jurnal Pendidikan Biologi 6(1): 260-266.

[13]. Pransiska, S., Asyhar, R., dan Asrial. 2016. Pengaruh Penerapan Model Pembelajaran Group Investigation dan Motivasi Terhadap Hasil Belajar Siswa Kela VII SMP Dalam Pembelajaran IPA Terpadu Pada Materi Asam, Basa dan Garam. Edu-Sains 5(2): 2731.

[14]. Awe, E.Y., dan Benge, K. 2017. Hubungan antara minat dan motivasi belajar dengan hasil belajar ipa pada siswa SD. Journal of Education Technology 1(4): 231-238.

[15]. Nugroho, B.W. 2016. Hubungan Motivasi Belajar dengan Hasil Belajar Kognitif dan Tanggung Jawab Siswa Kelas IV SD. Jurnal Pendidikan Sekolah Dasar. 37: 1-12.

[16]. Pangestika, S. 2018. Hubungan rasa percaya diri dengan motivasi berprestasi pada mata pelajaran IPA. Jurnal Pendidikan Guru Sekolah Dasar 10: 965-974.

[17]. Bakar, A., Dewi, F., dan Syafira. 2017. Analisis keterlaksanaan model attention, relevance, confidence, and satisfaction pada pembelajaran hidrokarbon dan pengaruhnya terhadap kepercayaan diri siswa. J. Indo. Soc. Integ. Chem 9(2): 1-7.

[18]. Sugiartini, N.K., Pudjawan, K., dan Renda, N.T. 2017. Hubungan pola asuh orang tua dan rasa percaya diri terhadap hasil belajar IPA kelas V. Mimbar PGSD 5(2): 1-10.

[19]. Kusyairy, U. 2015. Hubungan antara kematangan emosi dan kepercayaan diri dengan sikap belajar siswa pada mata pelajaran fisika di kelas XI IPA SMA negeri 1 Belopa Kab. Luwu. Jurnal Pendidikan Fisika 3(1): 58-61. 